\title{
Una nueva sátira sobre el traslado de la Corte: El romance «Señora Valladolid»
}

ROSA NAVARRO DURÁN Universidad de Barcelona

Gracián, en su Agudeza y arte de ingenio, al hablar «de la perfección del estilo» formulará algunas ideas que serán citadas siempre al definir el conceptismo: "Son las voces, lo que las hojas en el árbol, y los conceptos el fruto", "Mas el nervio del estilo consiste en la intensa profundidad del verbo», «Preñado ha de ser el verbo, no hinchado; que signifique, no que resuene» ${ }^{1}$. Y subraya la necesidad de adecuar el concepto al poema: el decoro o la decencia así lo exige, "porque el [concepto] que es nacido para un epigrama, no es decente para un sermón» ${ }^{2}$. Incluso inicia una enumeración de correspondencias entre estrofa y conceptos, y dirá del romance: «El romance quiere conceptos galantes más que profundos; figuras retóricas, más de la palabra que de la sentencia; estilo florido y bizarro" ${ }^{3}$. No distingue en él diversidad por el contenido como va a hacer con el soneto: «El soneto corresponde al epigrama latino, y así requiere variedad; si es heroico, pide concepto majestuoso; si es crítico, picante; si es burles-

\footnotetext{
1 Edic. de E. Correa Calderón, Madrid, Castalia, 1969, II, pp. 229, 234.

2 Ibid., p. 231.

3 Ibid., p. 232.
} 
co, donoso... $\rangle^{4}$. El romance no tiene antecedente clásico que lo dignifique y así será visto como forma de expresión del estilo humilde. Sin embargo, es indudable que también su contenido condiciona la lengua. Un ejemplo claro lo tenemos en los romances satíricos, donde las plumas mordaces de los geniales Góngora y Quevedo crean unos juegos agudísimos. «En el ápice del ingenio aparece el recurso verbal que podemos designar con los nombres de silepsis, dilogía o disemia» dirá Lázaro Carreter ${ }^{5}$, y lo burlesco, lo satírico tiene su punto de apoyo en esos juegos de palabras. Un riguroso estudio del romancero satírico nos ofrecería numerosísimos ejemplos. Para enriquecer su acervo y subrayar algunos juegos conceptuosos, voy a exhumar un curioso y largo romance burlesco sobre el traslado de la corte a Valladolid. Se halla copiado entre los folios 196-199v. del ms. 3.857 de la Biblioteca del C. S. I. C. de Madrid, perteneciente al fondo Rodríguez Marín. El códice es un volumen facticio copiado en Sevilla a principios del siglo XVII, aunque algún cuadernillo puede haberlo sido un poco antes ${ }^{6}$. Sólo hay en él otra composición transcrita por el mismo copista, es la «Elegía de D. Fernando de Guzmán a la muerte de don Agustín de Cetina, hijo del contador Agustín de Cetina» ${ }^{7}$, con fecha de 1601 , muy cercana a la del romance, porque por la novedad con que se refiere al período de Corte en Valladolid (1601-1606), es más verosímil datarlo al comienzo de tal etapa.

El autor se dirige a la ciudad personificándola, «Señora Valladolid», y desvela el tema en los vv. 41-2: «Valladolid en Castilla, / ya de todo el mundo reyna». El v. 61 lo sitúa en la época

4 Ibíd.

5 «Sobre la dificultad conceptista», en Estilo barroco y personalidad creadora, Madrid, Cátedra, $1977^{3}$, p. 24.

6 F. Rodríguez Marín lo menciona en su edición crítica de Rinconete y Cortadillo, Sevilla, Tip. de F. de P. Díaz, 1905, p. 153, nota 4; en «Una sátira sevillana del licenciado Francisco Pacheco», Revista de Archivos, Bibliotecas y Museos, XVII, 1907, p. 3 y en «La Segunda parte de la vida del pícaro con algunas noticias de su autor», Revista de Archivos, Bibliotecas y Museos, XVIII, 1908, p. 71.

7 Vide mi artículo «Nuevos datos sobre el poeta Fernando de Guzmán», en Miscel-lània en honor del Dr. Antoni Comas, Universidad de Barcelona, en prensa. 
histórica: «ya que al terçero Philippo [hospeda]», y los vv. 93-5 parecen aludir a lo reciente del hecho, reincidente también, «ya que todos quantos digo / nuebamente los ospeda / para pena de Madrid». «Señora Corte» le llama en el v. 125. Y al final resumirá su propósito el autor: «Perdone si en modo humilde / traté de sus exçelençias» (vv. 177-8), «excelencias» que le llevan a crear la curiosa sátira cortesana que transcribo a continuación ${ }^{8}$ :

Señora Valladolid,

si a su merçed se le acuerda

del tiempo que fue villana,

de don Pero Ançures dueña,

$5 \quad$ cuando la llamaron rica

y eran todas sus riqueças

muchas guindas de Simancas,

muchas roscas de Tudela;

cuando fue su turbio amante

10 el viejo aguador Pisuerga, y Esgueba, sucia de vasos, fregona de su limpieza;

cuando su cuerpo abrigauan

por ser de çelebro fresca,

15 de Medina los gauanes, las freçadas de Palençia;

cuando Toroços malquisto,

su acemilero de leña, onrró con fuego sus lares,

20 aunque ya salado tienbla; cuando con crenchas partidas

f. $196 \mathrm{v}$. venían a ber sus fiestas de Zamora doña Urraca, de Burgos doña Ximena;

25 si se le acuerda de todo, bien berá las diferençias

8 La lectura de algunos versos es dificilísima porque la tinta casi ha desaparecido por unas manchas de humedad que estropean la parte inferior de los folios (sobre todo el 198v.). Mantengo las grafías, pero acentúo y puntúo según las normas académicas. 
que representa en el mundo

Fortuna, autor de tragedias,

y que el sol y el hombre, solos

30 padres de quanto se engendra, para que una cossa nazca diçen que otra cossa muera; enblema de que la edad, como noria dando bueltas,

35 tal vez los llenos derrama y tal los vaçíos llena.

Muy geroglífico estoy, ora bien mudemos tema, mezclemos con esto grave

40 algo dulçe que entretenga.

Valladolid en Castilla, ya de todo el mundo reyna, por mil años cortesana y por ninguno corte enferma,

45 palabras quiero tener esta tarde con su alteça, y pues no me da posada, por merçed que me dé audiençia.

Yo soy vn honbre de pluma,

50 aunque sin alas que puedan leuantarme de mi estado porque las rinde gran piedra.

Soy un medio censurante entre Zoýlo y poeta,

55 más escrito que leýdo como el son de Juan de Mena.

Deseo, pues, que me escuche porque en mí Galeno vea que regimiento en salud

60 de enfermedades preserua. Ya que al ${ }^{9}$ terçero Philippo, 
a sus armas y a sus letras,

y a sus délficos talares

que dan divinas respuestas;

al antípoda remoto,

al galo, al ytalo, al velga;

al discreto pensatibo

y al neçio que nada piensa;

al pleyteante rendido,

f. $197 \mathrm{v}$.

70 al que escriue y al que alega,

al agente estafador

que más que mereee medra;

al mirabel bagamundo

de copete y sienes crespas,

75 garabato de vil gom, de Caco llabe maestra;

a vellas mal maridadas,

a Didos, viudas siqueas ${ }^{10}$,

a sirenas engañosas,

80 carne, pescado y donçellas;

al mohatrero prestante, lazo de pobres haçiendas;

al garito que descassa,

a la cassante truchuela,

85

al lenon manso in vtroque ${ }^{11}$, corchete vil de su henbra, lima sorda de su cassa ${ }^{12}$, nabaja de las agenas;

al fin, al bueno y al malo,

90 a la mala y a la buena, que de los reyes las cortes

10 Siqueas, de Siqueo, marido de Dido.

11 Lenon, alcahuete. In utroque, cfr. Quevedo, «La toma de Valles Ronces»: «¿A dónde está el cardenal, / casamentero in utroque» (vv. 21-22), Obra poética, ed. de J. M. Blecua, Madrid, Castalia, 1971, III, p. 467.

12 Lima sorda, «Metaphóricamente se llama el tiempo, y todo aquello que imperceptiblemente y sin sentir va gastando y consumiendo alguna cosa». Se opone esa lentitud y disimulo a la "navaja» o «lengua de los maldicientes y murmuradores porque con ella cortan y hieren la honra y el crédito». Dicc. de Auts. 
se visten de varias mezclas;

ya que todos quantos digo nuebamente los ospeda

95 para pena de Madrid,

mal dicho, para enmienda,

que de no purgarse en tiempo

vino a estar ynchada y gruessa,

tanto que ynportó sangralla

100 aprissa de todas venas.

Era glotona epicúrea, pero ya comiendo dieta de sus muchas noches haçe día y noche penitençia.

105 Recogíase muy tarde, mas, porque reposse y duerma, a la queda le an tañido vadajadas de paçiencia;

mucha justicia la ronda,

110 muchos la guardan y çelan, más por la espada que quitan que por la vida que enmiendan.

Mandaba a sus regidores y ellos oy en la cabeza

115 le ponen zeniça y diçen: «Reconoçe que eres muestra».

Troya, Cartago y Sagunto con ruynas la consuelan mostrando que nadie tubo

120 ciudad que perpetua sea.

¡O tiempo! ¿tus alas libres?

f. $198 \mathrm{v}$. Mas, ¡O Fortuna!, ¿tu rueda?, ¿qué no bencen?, ¿qué no acaban? ¿qué no pasan?, ¿qué no truecan?

125 Digo, al fin, señora Corte, que porque a los suyos tenga en tan amigo ospedaje que dure edades inmensas, 
cante siempre el conde Claros

130 el çielo alegre en su tierra y no de Leandro y Ero las nubes y las endechas.

De tornasol y de rasso galas haga, que libreas

135 y sus chamelotes de agua para la Mancha los venda.

Sereníssima señora por corona y mitra sea, sin permitir que la llamen

140 serrana de escarcha nieblas, ni que viba en Polvorança los meses de ardientes siestas, y los demás, salpicada, por los lodos se pasea.

145 No se encrezca ni [se] ensanche, que no es Castilla la Vieja, y viejas $\sin$ artificio poco tiempo se sustentan.

Salga de madre su río,

150 y assí como el Nilo riega

a Egipto, riegue sus bocas de su multitud sedienta, que se quejan que no ay agua en golfo cuyas galeras

155 sustenta[n] dos magestades, a quien Neptuno respeta.

No permita que mosquitos su faz beneranda ofendan, que no es ella faraona

160 para que plagas padezca.

A los que de ella murmuran -que muchos murmuran de ella, tal porque no le a llamado $y$ tal porque le desecha-,

respóndales que a mill años 


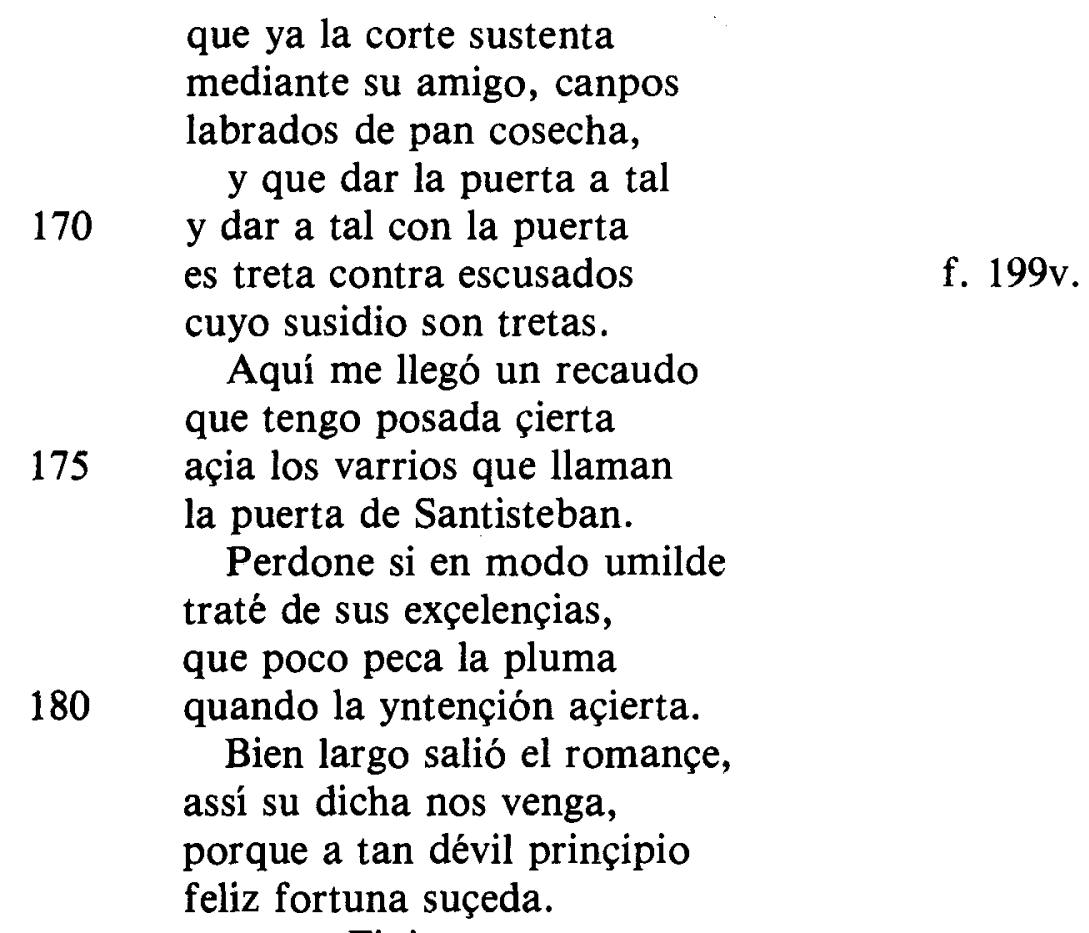

Finis.

La habilidad versificadora del autor le permite no basarse constantemente en la unidad de la cuarteta (aunque ésta se mantenga) para expresar las ideas; a veces se encadenan a lo largo de muchos más versos, como la larga enumeración que va de los vv. 61 al 92, o incluso ensaya algún brusco encabalgamiento como el de los 150-2: «y assí como el Nilo riega / a Egipto, riegue sus bocas / de su multitud sedienta».

Los juegos de palabras son continuos, y frecuentes los términos cultos, «délficos talares», «epicúrea» junto a los truhanescos («mohatrero», "garito», «lenon», etc.). La riqueza de lo apuntado a través de lo dicho es tal que el lenguaje se hace difícil de descifrar. Es innegable la maestría y la pluma mordaz e ingeniosa del autor.

El apóstrofe a Valladolid, hecha «señora» en su personificación, nos es familiar gracias, entre otros, a los geniales Góngora y 
Quevedo. Desde los sonetos gongorinos «¿Vos sois Valladolid?, ¿Vos sois el valle?» $\mathrm{y}$ «Valladolid, de lágrimas sois valle» ${ }^{13}$, ambos de 1603, a «No fuera tanto tu mal, / Valladolid opulenta», el romance de Quevedo ${ }^{14}$. Pero sus ríos, Pisuerga y Esgueva, son blanco de los versos del genial cordobés: «¿Qué lleva el señor Esgueva?», la famosa letrilla, se une a los sonetos «Jura Pisuerga a fe de caballero» $\mathrm{y}$ " $\mathrm{i}$ Oh qué malquisto con Esgueva quedo» ${ }^{15}$, los tres poemas de 1603 también.

El recuerdo del pasado de Valladolid «el tienpo que fue villana» es el tema de los 24 primeros versos, y aprovecha el autor para mencionar lo turbio del Pisuerga y la suciedad de Esgueva en una de las cinco cuartetas precedidas por «cuando» que componen el rememorar sus humildes orígenes:

Cuando fue su turbio amante

el viejo aguador Pisuerga

y Esgueba, sucia de vasos,

fregona de su limpieza...

(vv. 9-12)

Góngora, que hace llevar a Esgueva parecida carga: «las cosas que por la vía / de la cámara han salido» (y así de él se avergüenza Pisuerga ${ }^{16}$ o de él se apartan los álamos: «porque el sucio Esgueva es tal / que ni aun los álamos quieren / dalle sus pies a besar» ${ }^{17}$, también menciona el pasado villano de Valladolid: «y cortesano sucio os hallo agora, / siendo villano un tiempo de buen talle» ${ }^{18}$. El poeta cordobés apostrofa al Tajo de forma parecida en «A vos digo, señor Tajo», y el «si a su merçed se le acuerda» con que comienza la evocación del pasado villano de

13 Obras completas, edic. de J. e I. Millé y Giménez, Madrid, Aguilar, 19726, pp. 472-3.

14 Obra poética, II, pp. 476-82.

15 Obras completas, pp. 327 y $471-72$.

16 Ibid., pp. 471-2; vv. 1.4 de «Jura Pisuerga a fe de caballero».

17 Ibid., p. 200; vv. 6-8 de «Al pie de un álamo negro». Quevedo no le irá a la zaga:

Pero el misero Esguevilla

se corre y tiene vergüenza

de que conviertan las coplas

sus corrientes en correncias.

(vv. 57-60 de «No fuera tanto tu mal», edic. cit., II, p. 478)

$18 \mathrm{Vv}$, del soneto «Valladolid, de lágrimas sois valle», edic. cit., p. 473. 
Valladolid tiene su equivalente en el v. 29 del romance gongorino: «acordaos de todo aquesto" y ello ha sido, por ejemplo, «Vos, que en las sierras de Cuenca / (mirad qué humildes principios) / nacéis de una fuentecilla / adonde se orina un risco" (vv. 21-4). El origen es aquí espacial, mientras a Valladolid se le mientan sus principios en el tiempo, igualmente humildes: «del tiempo que fue villana, / de don Pero Ançures dueña» (vv. 3-4). Como al conde Pero Ansúrez se le atribuía la fundación de Valladolid, Quevedo también lo menciona en el romance «Alabanzas irónicas a Valladolid, mudándose la Corte de ella»: «Todo pudiera sufrirse, / como no se le subieran / al buen Conde Peranzules / a la barba larga y espesa» ${ }^{19}$. Como evocación de ese tiempo pasado, el poeta menciona a doña Urraca y doña Ximena, rivales en algunos romances por el amor del Cid:

Cuando con crenchas partidas

venían a ber sus fiestas

de Zamora doña Urraca,

de Burgos doña Ximena.

(vv. 21-4)

Con igual finalidad se las nombra, de modo más arbitrario todavía, ya que no se pretende aludir en él a una época histórica, en el romance "Voto a Dios, señor Cupido»:

Ya se passó aquella edad, quando Hurraca con Ximena se juntauan a labrar sus derechuelos la fiesta. ${ }^{20}$

"Cuando la llamaron rica» (v. 5) sigue evocando el texto, y efectivamente es el adjetivo que se le aplica a la ciudad, así en "Llegado es el rey don Sancho», éste le promete a D. ${ }^{2}$ Urraca "a Villalpando y su tierra, / o Valladolid la rica», y Quevedo comienza un romance burlesco: «De Valladolid la rica» ${ }^{22}$, pero se burla al añadir «de arrepentidos de verla». 
El tema del romance es la contraposición entre Valladolid, cortesana y rica, y Madrid, pobre y abandonada. Tres romances de la Segunda parte del Romancero General de Miguel de Madrigal hablan del mismo hecho: "Vuestra patria y vuestra corte» (f. $22 \mathrm{v}$. y r.) ${ }^{23}$, donde Madrid le pide al monarca que no se marche, y los siguientes, enlazados entre sí: «Madrid y Valladolid» y «Señora doña Madrid», que comienza como el que comentamos, aunque dirigido a la ciudad rival (fols. 22v.-23r.) ${ }^{24}$, ambos de Alonso de Ledesma ya que aparecen recogidos, con variantes, en su Romancero y monstro imaginado (Madrid, 1615), fols. 37r.-40r., como señala Miguel D’Ors en Vida y poesía de Alonso de Ledesma ${ }^{25}$.

Wilson en «Samuel Pepys's Spanish Chap-books, part I» ${ }^{26}$ describe un pliego suelto $\left(n .^{\circ} 6 / 142\right)$ que tiene el romance «Señora Doña Madrid»: Relación verdadera que da cuenta de un grandioso milagro que obró la Virgen del Rosario [...] Lleva al fin tres romances muy curiosos [...] El segundo, la respuesta de Valladolid a Madrid (Sevilla, por Juan Vejarano, 1682). Y señala Wilson su presencia como $2 .^{\circ}$ poema en un pliego suelto (British Museum 11450, e. 25) impreso en Barcelona, en casa Sebastián de Cormellas, 1601 y que comienza con el anterior: Competencia entre las dos villas, Madrid y Valladolid, sobre la yda de su Magestad a Valladolid. Madrid ridiculiza a Valladolid en el primer poema y sólo la intercesión de Segovia frena la lengua de su contraria, en cuya boca está puesto el siguiente, su réplica.

El retrato de ambas apunta a esa riqueza y miseria que es la base común de la sátira:

Madrid vino como viuda [...]

Es un pedernal su pecho, mas sacan miserias tales, como vara de Moysén agua de sus pedernales.

Segunda parte del Romancero general, I, pp. 114-17.

Ibíd., pp. 117-121.

Pamplona, Eunsa, 1974, pp. 66-67.

Transactions of the Cambridge Bibliographical Society, II, 2, 1955, pp. 146-48. 
En trage de ciudadana por el otro lado sale la rica Valladolid, tan señora como graue. Era una villana hermosa...

(vv. 5, 9-17).

$Y$ de nuevo encontramos la alusión a su origen «villano». Madrid le echa en cara, además de su clima - que será tema a comentar en nuestro romance- la carencia de lugares y bosques para hospedar a los monarcas: «¿Dónde le piensa hospedar, / y lleuarle donde cace, / si no le presta Segouia / sus bosques y Casas Reales?» (vv. 45-8). Pero Valladolid, además de rebatir sus acusaciones, le recuerda sus orígenes labradores y vemos así la réplica al cartel de «villana» que siempre le cuelgan a esta ciudad:

\footnotetext{
Pues que ya se va a acostar, desnude bordadas ropas, y vista sayal mañana, pues que nació labradora. Tome zurrón y cayado, que a la larga o a la corta, buelue el agua a su carril, y la villana a su choça.
}

$$
\text { (vv. 41-48). }
$$

Góngora, que también utiliza la oposición villana/cortesana, señala la suciedad que el cambio comportaba: «Pisado he vuestros muros calle a calle, / donde el engaño con la corte mora, / y cortesano sucio os hallo ahora, / siendo villano un tiempo de buen talle» (vv. 5-8 de «Valladolid, de lágrimas sois valle»).

Valladolid consigue la corte y la riqueza a costa de Madrid, y así la reflexión sobre la veleidosa fortuna, que, para subir a unos, a otros baja, cierra esa primera parte mencionada del pasado «villano» de la ciudad. La imagen de la noria que hace plástica tal realidad:

Como noria dando bueltas, tal vez los llenos derrama y tal los vaçíos llena. 
la encontramos también en la «Desengañada exclamación a la Fortuna» de Quevedo ${ }^{27}$ :

Bestia de noria, que, ciega, con los arcaduces andas, y en vaciándolos, los llenas y en llenándolos, los vacias.

$$
\text { (vv. 5-8). }
$$

El poeta señala su cambio de tema: «muy geroglífico estoy, / ora bien mudemos tema..." (vv. 37-8) y comienza la enumeración de los huéspedes de Valladolid, o de su corte. Le pide audiencia para que le escuche «pues no me da posada» (v. 47) y sus palabras le curen en salud (vv. 57-60). Para ello se presenta como «hombre de pluma / aunque sin alas que puedan / leuantarme de mi estado» (vv. 49-51) y juega con la dilogía que la polisemia de la palabra "pluma» permite ${ }^{28}$, como antes ha unido el calambur a la antítesis ("cortesana / corte enferma») (vv. 43-44) ${ }^{29}$. Sigue definiéndose: "Soy un medio censurante / entre Zoylo y poeta». Utiliza una frase hecha para ironizar sobre su limitado éxito: «más escrito que leýdo, / como el son de Juan de Mena» (vv. 55-6), aunque el cliché más corriente sea el que Góngora utiliza en «A vos digo, señor Tajo»: «en España más sonado / que nariz con romadizo, / famoso entre los poetas, / tan leido como escrito" ${ }^{30}$, con ambos conceptos a la par, como en el roValladolid la rica»:

$\mathrm{Si}$ algo pudieren mis versos, puedes estar, Madrid, cierta que has de vivir en mis plumas, ya que en las del tiempo mueras.

(vv. 109-112; ed. cit., III, p. 139)

En nuestro romance se habla de las alas del tiempo: «O tiempo!, ¿tus alas libres?» (v. 121), que aclara el término.

29 Como es bien sabido, Góngora y Quevedo son muy aficionados a tales juegos: el «ruiseñores / ruicriados» de los vv. 10-11, «Tenedme, aunque es otoño, ruiseñores, / ya que llevar no puedo ruicriados», de «iMal haya el que en señores idolatra» (Obras completas, p. 581) es un ejemplo de ello.

30 Ibíd., p. 122; vv. 7-10. 
mance de la Segunda parte del Romancero General «Escuchadme, Ninfas bellas, / damas de Valladolid, / más escritas y leídas / que el encantado Merlín» ${ }^{31}$.

La enumeración de personajes se cierra con el dístico que la justifica: «que de los reyes las cortes / se visten de varias mezclas» y esta palabra presenta el equívoco de su doble significado, el que encaja con el verbo "vestirse», "contextura de diversas colores en los vestidos» (Dicc. Auts.) y el que alude a la unión de todos los seres que ha mencionado. Entre ellos hospeda, «al mirabel bagamundo, / de copete y sienes crespas, / garabato de vil gom», ejemplo de la dificultad de la lengua utilizada; así, según el Dicc. de Auts., «mirabel» es «una flor de muchas hojas, de color amarillo u dorado, que aunque es hermosa a la vista, no tiene olor». A este personaje le hubiese afectado la prohibición del 13 de abril de 1639 que «ningún hombre pueda traer copete o jaulilla, ni guedejas con crespo u otro rizo en el cabello, el cual no pueda pasar de la oreja». Y además es «garabato» o ladrón, «mi aire lleva las capas; / las bolsas, mi garabato» dice Quevedo ${ }^{32}$; "de Caco llabe maestra» (v. 76), y Quevedo de nuevo utiliza el término «Discreteando a lo feo, / y desnudando a lo Caco» ${ }^{33}$. Otros personajes serán vistos también de forma quevedesca, así las «sirenas engañosas, / carne, pescado y donçellas» (vv. 79-80) recuerdan unos versos de las «Advertencias de una dueña a un galán pobre» ${ }^{34}$ : «una de aquestas que enviudan / y en un animal se vuelven, / que ni es carne ni pescado, / dueña, en buena hora se miente» (vv. 9-12).

«A la cassante truchuela» (v. 84), es decir, bacalao, pez que simboliza la Cuaresma, la no "carnalidad», la asociamos con las mujeres abadejos de Quevedo, así en el baile de «Los Nadadores», entre un desfile de diversos pescados, nadadores «en el mar de la Corte», encontramos las «tapadas de medio ojo / cada pun-

31 Edic. cit., II, p. 107.

32 Obra poética, II, p. 271; vv. 51-52 de «Si me llamaron la Chica».

33 Ibíd., p. 265; vv. 29-30 de «Allá van nuestros delitos».

34 Ibíd., p. 382; vv. 9-12 de «Una picaza de estrado». 
to se hallan, / abadejos mujeres, / arremendando caras» ${ }^{35}$, o entre las que se bañan en el Manzanares: «No todas nadan en carnes / las señoras que publico: / que en pescados abadejos / han nadado más de cinco» ${ }^{36}$.

Tras el desfile se inicia la visión de la abandonada Madrid en penitencia por sus excesos.

Y si Góngora llama «Babilonia» a Valladolid ${ }^{37}$ en «Llegué a Valladolid; registré luego», Quevedo llamará a Madrid «Jerusalén asolada, / Troya por el suelo puesta, / Babilonia destrüida» (vv. 97-99 del romance burlesco «De Valladolid la rica») ${ }^{38}$. Y a su miseria tras el traslado de la corte la dedica la letrilla burlesca "Después que me vi en Madrid, / yo os diré lo que vi» ${ }^{39}$, donde entre otras visiones de su abandono dirá: «vi muchas puertas cerradas / y un pueblo echado por puertas» (vv. 34-5). Nuestro poeta mantiene la personificación y la pinta como era: «era glotona epicúrea» (v. 101) [...] «recogíase muy tarde» (v. 105) y cómo su conducta ha cambiado. Sus regidores «oy en la cabeza / le ponen zeniça y dicen: / «Reconoçe que eres muestra» (vv. 114-6) y recuerdan estos versos a los que terminan el romance de Quevedo «No al son de la dulce lira» ${ }^{40}:$ «Recibid bien la ceniza / que en vuestras frentes os pongo, / y acordaos de que sois tierra / y que os volveréis en lodo" (vv. 73-76), aunque el desengaño sea general en él a partir de una sátira a una dama. También acabará con una visión de ruina de Madrid el citado «De Valladolid la rica», de donde puede sacarse «aviso»; antes lo hemos visto como «muestra» o señal, indicio:

\section{Eres lástima del mundo, desengaño de grandezas, cadáver sin alma, frío, sombra fugitiva y negra, aviso de presunciones...}

(vv. 101-105).

Ibíd., III, p. 387; vv. 37-40.

Ibíd., II, p. 400; vv. 65-68 de «Manzanares, Manzanares».

Ed. cit., p. 471.

Obra poética, III, p. 137.

Ibíd., II, p. 191-92.

Ibid., III, p. 183. 
En nuestro romance recibe consuelo «con ruinas» de «Troya, Cartago y Sagunto» (v. 117), los ejemplos siempre aludidos, de esplendor en ruinas. En el romance antes citado «Vuestra patria y vuestra corte» ${ }^{41}$, en boca de Madrid, menciona a los regidores, pero sólo como artífices de su esplendor: «Mis antiguos Regidores / comenzaron a hacer / admirables adificios / que sin vos han de caer» (vv. 33-6), y más adelante se identifica también con Troya: «y dirán: - «Aquí fue Troya, / adonde Madrid fue ayer» (vv. 63-4).

Sigue una cuarteta con apóstrofes al tiempo y a la fortuna con cuatro interrogaciones retóricas que rompen dos versos en dos hemistiquios tetrasílabos: "¿qué no bencen? ¿qué no acaban? / ¿qué no pasan?, ¿qué no truecan? (vv. 123-4), muy expresivos y que inciden de nuevo en el tema desarrollado en los vv. 28-36. También sirven de cierre de este subtema analizado y el autor reemprende el diálogo con Valladolid y su deseo de que le dure su estado, cosa que no sucedería:

\section{Digo, al fin, señora Corte que porque a los suyos tenga en tan amigo ospedaje que dure edades inmensas...}

(vv. 125-8).

A partir del v. 129 comienza una serie de deseos y consejos que dirige a la ciudad con los consabidos juegos conceptuosos. Se le podría aplicar lo que dice el autor del romance «Ya yo he dado en gentilhombre» de la Segunda parte del Romancero General después de unos de ellos: «He dado en ser jugador, / y estoy tan pobre y tan ruyn, / que hasta los vocablos juego, / como lo auréys visto aquí» ${ }^{42}$.

Le desea felicidad y para ello opone al conde Claros de Montalván (personaje de romances cuya historia tiene un final feliz tal como aparece en «Media noche era por filo») a Hero y Leandro, con su destino trágico. Y si éstos dieron materia a Góngora

2 Ibid., I, p. 37. 
y Quevedo para sus sátiras (desde la famosa «Arrojóse el mancebito» a "Señor don Leandro»), abundan asimismo las alusiones al primero por el fácil juego de voces que proporciona su nombre. Dice Quevedo: "Mas como los condes / la claridad gozan / desde el Conde Claros, / todo será sombras» en su romance «Erase una cena» ${ }^{43}$. Y el autor del romance aprovechará tal facilidad y opone, junto a los personajes, «el cielo alegre» a «las nubes»»:

Cante siempre el conde Claros

el çielo alegre en su tierra

y no de Leandro y Ero

las nubes y las endechas.

(vv. 129-132).

Y no abandonará la alusión al tiempo de la ciudad. Telas le permitirán seguir el juego de voces y del mismo modo que Quevedo juega con el «raso», por ser poco frecuente en Valladolid el tiempo sereno, él lo hace con "tornasol», "chamelotes de agua» junto a ese mismo vocablo. Quevedo en «Diéronme ayer la minuta» dice: «Fue yerro pedirme raso / en Valladolid la bella, / donde aun el cielo no alcanza / un vestido de esa seda» (vv. 37-40) entre otros equívocos («tela», «brincos», «martas», etc.), y los vv. 133-136 de «Señora Valladolid»:

\footnotetext{
De tornasol y de rasso

galas haga, que libreas

y sus chamelotes de agua

para la Mancha los venda.
}

El vocativo «Sereníssima señora», con que se dirige a la ciudad, cobra nuevo sentido en ese contexto, y el tiempo sereno evocado inicia otras asociaciones climáticas que abarcarán dos nuevas cuartetas. Si no tiene que permitir que la llamen «Serrana de escarcha nieblas / ni que viba en Polvorança» (vv. 140-1), tenemos el doble sentido nobiliario-meteorológico. El Sr. de Polvoranca era el famoso amigo de Góngora don Antonio Chacón, y el undécimo conde de Niebla era Manuel Alonso Pérez de Guzmán, también duque de Medina Sidonia. Casó con Juana de Sandoval

Obra poética, III, p. 203; vv. 131-4. 
y de la Cerda, hija del duque de Lerma, valido de Felipe III, de quien partió la idea del traslado de la corte a Valladolid. Aunque la alusión directa es posible, creo que el propósito es sólo el juego de voces, así lo hace Góngora en el terceto final del soneto «Valladolid, de lágrimas sois valle» ${ }^{44}$ : "No encuentra al de Buendía en todo el año; / al de Chinchón sí ahora, y el invierno / al de Niebla, al de Nieva, al de Lodosa».

Antonio Vilanova, al comentar el v. 5 del Polifemo gongorino, «ahora que de luz tu Niebla doras», dice:

...Con anterioridad a Góngora, los juegos de palabras en torno a la anfibología de la palabra Niebla, en su doble acepción de Niebla "conde de» y niebla «fenómeno natural», eran muy frecuentes en la poesía española de la época, debido a la ilustre estirpe de los Guzmán, a la que el título estaba vinculado, y al generoso esplendor de la casa de Medinasidonia. Parece, sin embargo, que el verdadero creador de este juego de palabras fue nada menos que Lope de Vega, en su poema en octavas Fiesta de Denia (1599)... ${ }^{45}$.

Todavía se podría profundizar más en la doblez significativa de los vocablos porque «escarchar» significa también «rizar o encrespar» y de niebla dice el Dicc. de Auts.: «metaphóricamente vale la confusión y obscuridad que no dexa percebir o hacer juicio de las cosas». Puesto que estamos en la corte, sería apropiado también el significado metafórico, aunque basta la inicial dilogía.

Por tanto, el juego evidente es con el valor real del término «niebla», por lo que Valladolid se caracteriza. En el romance citado «Madrid y Valladolid», Madrid se lo echa en cara:

¿Es por dicha más hermosa

una muger de mal talle, con mil nubes en los ojos, y con mil nieblas delante?

(vv. 29-32).

y ella le replica en el siguiente «Señora doña Madrid» de esta manera:

44 Obras completas, p. 473.

45 Las fuentes y los temas del «Polifemo» de Góngora, Madrid, C. S. I. C., 1957, I, p. 172. 
Mis nieblas y corrimientos

los he tenido hasta agora, por estar el sol tan lexos, que el inuierno engendra sombras

(vv. 13-16).

Lo mismo ocurre con «Polvorança», cuya raíz «polvo» adquiere sentido con los vv. siguientes: «ni que viba en Polvorança / los meses de ardientes siestas / y los demás, salpicada, / por los lodos se pasea» (vv. 141-144). La sequedad de Valladolid queda destacada en el citado «Madrid y Valladolid»: «Las márgenes de sus ríos / son dos secos arenales, / sin flores que le coronen, / sin árboles que le guarden» (vv. 53-56). Y el «lodo» (que tiene la ambigüedad de su sentido real y ético y con él el vocablo «salpicada») es elemento propio de las calles vallisoletanas, como dice Quevedo:

No quiero alabar tus calles, pues son, hablando de veras, unas tuertas y otras bizcas, y todas de lodo ciegas ${ }^{46}$.

El término va unido al anterior «Polvorança» por el refrán que dice «de aquellos polvos vienen estos lodos». Góngora en la definición de la Corte enumera a los «lodos con perejil y yerbabuena» que la caracterizan ${ }^{47}$.

Su no pertenencia a Castilla la Vieja le permite al autor jugar con el término «artificio»: «y viejas sin artificio / poco tiempo se sustentan» (vv. 147-8), en que se refiere a «Castilla» o castillo como «obra executada según arte y sus reglas, o con novedad, primor y sutileza» y al «artificio» o «fingimiento y maña» necesario para disimular la vejez. Los vv. 25-28 del citado «Señora doña Madrid» aluden a la oposición de las dos ciudades por pertenecer ésta a Castilla la Vieja:

Quando allá fue claro día, acá noche tenebrosa, por ser Castilla la vieja los Antipodas de essotra.

46 Obra poética, II, p. 476; vv. 13-16 de «No fuera tanto tu mal».

47 Edic. cit., p. 459; v. 13 de «Grandes, más que elefantes y que abadas». 
Egipto le va a proporcionar al autor material para sus «conceptos».. Primero con un símil que parte del caudal del Nilo, siempre término hiperbólico de la mucha agua. Tiene que, como él, regar, pero las «bocas de su multitud sedienta», no de agua, sino de riquezas o cargos - se supone-. En segundo lugar la plaga de mosquitos sufrida por el faraón (Exodo 8, 12-15) le lleva a otro oscuro juego de referencias:

\section{No permita que mosquitos su faz beneranda ofendan, que no es ella faraona para que plagas padezca.}

(vv. 157-160).

Y podría referirse con «mosquitos» a «los que acuden frecuentemente a la taberna» (Dicc. Auts.). Quevedo, que alude muchisimas veces a esos mosquitos del vino, juega con la misma idea en los vv. 48-50 de "Chitona ha sido mi lengua» ${ }^{48}$ : "y el aguado melindroso / le llama plaga de Egipto, / por los mosquitos del sorbo".

El último consejo que le da a Valladolid es contra los «murmuradores» que no han conseguido sus pretensiones. Termina con el anuncio de haber conseguido "posada çierta», la que en el v. 47 decía no obtener ( «y pues no me da posada»). Precisamente cuando mencionaba la falta de favores como motivo de las críticas, «que muchos murmuran de ella / tal porque no le a llamado / y tal porque le desecha» (vv. 162-4), él acaba la suya al recibir «posada».

Las dos últimas cuartetas son de cierre retórico, las consabidas excusas de falsa modestia, pero enriquecidas por la ironía que la realidad tan contraria del poema le da:

Perdone si en modo umilde traté de sus exçelençias, que poco peca la pluma quando la yntençion açierta.

(vv. 177-180). ces», el v. 13; «los mosquitos sean plaga a los testuces», ibíd., II, p. 45. 
Los buenos deseos se unen a la calificación cierta del romance como «largo» y a la puntilla de su ataque: «[...] a tan dévil prinçipio / feliz fortuna suceda» (vv. 183-4), que parece aludir claramente a esos primeros tiempos de Valladolid como cortesana, no muy afortunada, según la sátira.

El poema, pues, se encuentra dentro de las sátiras escritas durante el traslado de la corte a Valladolid. Muy superior a las dos citadas de la Segunda parte del Romancero General, algunos de sus versos se acercan a las geniales dilogías quevedescas y gongorinas.

Ya vimos que Gracián caracterizaba al romance por «figuras retóricas, más de la palabra que de la sentencia» y había dicho de "la «agudeza verbal» «que consiste más en la palabra; de tal modo que, si aquélla se quita, no queda alma, ni se pueden éstas traducir en otra lengua; deste género son los equívocos» ${ }^{49}$. Este romance burlesco de comienzos de 1600 -época del trascendental cambio artístico que fue el Barroco- nos ofrece una prueba más de cómo la forma estrófica, unida al contenido, condiciona el tipo de agudeza. 